\title{
充てん剂効果による小形電子部品用 保護塗料の耐湿性の改善
}

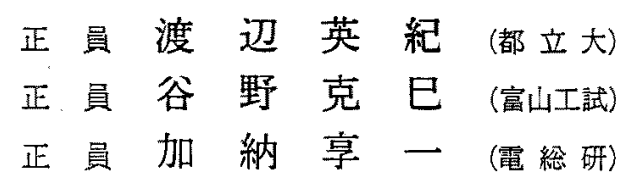

\section{1. まえがき}

近年の電子回路のモジュール化あ尚いはハイブリッ ドICの普及などに伴って，小形抵抗器、コンデンサ などいわりる沉用小形電子部品比対しても，他の構成 部品に見合った高い信賴性を要求される場合が少なく ない。

との種の部品は，その性質上なる心゙く簡単な工程で 安価偪産できることが肝要である。従って，防湿标 よび絶緑好理には，多くの埸合最む簡易な封止力法， すなわち保護塗料によるコーティングが行なわれてい る。現在用いられている塣料の大部分はエポキシ樹脂 系の焼付塗料である。エポキシ樹脂は一般に䋓縁性， 耐湿性，接着性，その他多くの点で優れた性質を兼備 している上考えられている。しかしながら，沉用電子 部品などに用いられる比較的安価な保護塗料には，植 物油を加えてエステル化したるのを用いる場合が多 く，その耐湿性は必ずしも良いとは言えない(1)(2)。そ のため，最近ではしばしば他の樹脂との併用などによ り性質の向上が图られてはいるが(3)，依然として小形 崡抗器などには耐湿信頼性の低いものが見られ，保護 塗料の耐湿性に一首の改善が望まれている。

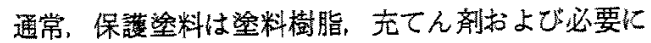
応じて顔料(着色剂)の3 喠類の成分加ら成るが，叙膜

\footnotetext{
Improvement in Moisture-Proof Characteristics of Paint Material for Electronic Parts by Means of Filler Effects. By Eiki Watanabe, Member (Department of Electrical Engineer ing. Tokyo Metropolitan University), Katsumi Tanino, Mamber (Industrial Research Institute, Toyama) \& Kyoichi Kanou, Member (Electronic Device Division, Electrotechnical Laboratory).

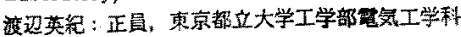

谷野克巴：正買，富山県工莱縒駰所

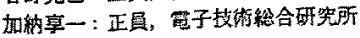

昭 $56-10$
の利湿性は主に整料樹脂によって決まる上考えられて いる。充てん斉の役割仙ついては種々列挙されてはい るが(4)，実際上は高価な樹脂成分を節約するための堌 量版としての役割以外仙あまり重要視されていない。 従って，その配合率む主に経済性とコーティング工程 亿坊ける作業性 (粱料の流動性)を勘案して経験的に決 定されているのが現状である。しかし一方では，いわ ゆる充てん剂効果，すなわち克てん剂の種類や配合率

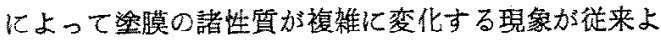
りしばしば報告されている(5)-(8)。また，充てん郕お よび顔料の主材料である種々の無機質粉体の化学的性 質についてむ研究が進み，塗料樹脂分子之の間の化学 反応の機構などす明らかにされている(9)。

そこで著者らは，電子部品の耐湿信頼性向上のため の研究の一環として，主に小形抵抗器用保護塗料とし て現在最も多く使用さ机ているエポキシ樹脂严梁料を 選び，充てん剂㧍よび顔料を種々の割合で配合した武 料を謂製して一連の而湿性評洒試娩を実施した。その 結果，特定の充てん剂配合率において塗料の耐湿性が 飛躍的に改善されることを見いだした。また，主に白 色梁膜の黄化を隠へいして部品の商品価值を維持する ことを目的として，カーボンブラックが比較的少量添 加されるが，その添加量によっては塗料の耐湿性に無 視できない影響を与えることが明らかとなった。

本論文では充て九剂勃果による耐湿性の改善枋よび 顔料の影響関する試針結果を報告し，塗料樹脂之充 てん斉および顔料との間の化学的な相互作用による耐 湿性改善の機構について考察する。更に種々の観点加 ら最良之考えられる配合率を決定して改めて保護深料 を調製し，無電界的っき抵抗体 ${ }^{(10)(11)}$ の実用化試験に 供したところ，満足すべき結果を得たことを述へる。 


\section{2. 試料}

$\langle 2 \cdot 1\rangle$ 塗料の調製 試駼汇用いた塗料の樹脂成 分は, ビスフェノール系エポキシ樹脂の大豆油脂肪酸 エステル (Shell : YS-5) に架橋剤としてブチル化メチ ロールメラミン $30 \%$ (重量比)を加えたメラミン併用 エポキシ・エステル (以後，ME と略記) である。こ れに充てん剂朽よび顔料として，それぞれチタンホワ イト(ルチル形二酸化チタン粉末; 平均粒径約 $0.22 \mu \mathrm{m}$ ) 抽ざカーボンブラック (以後，それぞれ TWおよ び CB と略記〉が配合されている。

今後，TW および CB の配合率がそれぞれ $x(\%)$ および $y(\%)$ の塗料または塗膜試料を $S_{x, y}$ 之書くこ とにする。ただし， $\mathrm{CB}$ を含まない試料（すなわち $y$ $=0$ の試料）については，yを省いて $S_{x}$ と畫く。ま た配合率は％で表わすが，すべて重量％の意味であ る。

充てん剂効果を調べるために用意した試料は，染料 樹脂のみの透明塗料 $\left(S_{0}\right)$ 扰上び $x=15,20,25$ の 3 種類の白色筀料 $\left(S_{x}\right)$ である。ここに，現在使用され ている多くの同種漼料について TW 配合率を調べた 結果加，実用上意味のある $x$ の下限を 15 とした。 実際には 20 25\% 程度のむのが多く用いられている。 $x=30$ の試料も調整を試みたが，流動性の低下がはな はだしく，均一な塗膜の作成が困難なため試験の対象 加ら除いた。

次に，顔料の影響を調べるために， $S_{20}$ および $S_{25}$ をべースとして更に $\mathrm{CB}$ を各々 2,5 拈よび $8 \%$ 配合 した质色泟料 $\left(S_{20, y}\right.$ およひ $\left.S_{25, y}\right)$ を調整しだ。ただ し, 特に $S_{25, y}$ では $y \geqq 5$ の染䑅の均一性が $x=30$ の 場合之同様の理由で十分でなく，各種の試験結果にも かなりのばらつきが見られたてとを付記する。

$\langle 2 \cdot 2\rangle$ 塗膜試験片の作製 $S_{x}$ および $S_{x, y}$ の塗 膜試験片多数を水銀はく離法により作製した。すなる ち，塗料を平坦な亜鉛びき鉄板(トタン板)の上に均一 に塗布して硬化させた後，鉄板の一端を水銀中に清し て一㡺夜放置する。その間䎲亜鉛層はアマルガム化し てペースト状となるので，塗膜を容易にはく離するこ とができる。染膜は酸珗，水洗の後，十分に乾燥して 実験供する。硬化条件は $150^{\circ} \mathrm{C} ， 1$ 時間で，塗膜の 厚さは $30 \sim 60 \mu \mathrm{m}$ 程度である。一試験条件あたりの試 験片の数仕 $3 \sim 5$ 枚で, 各試験の測定値としてはその 平均徝を用いた。

$\langle 2 \cdot 3\rangle$ 無電界めっき抵抗体試料(10)(11) 保護塗料 の耐湿性を電子部品に実際にコーティングした状態で 総合的に評価するために，無電界如き法により作製
された抵抗体素子（初期抵抗值：20 $\mathrm{k} \Omega \pm 10 \%$ ）を多数 用意した。との抵抗体は耐湿性が極めて悪く，防湿処 理なしで例えば後仪述べる温湿度処理 (III)のふんい気 中に 1,000 時間放置すると，抵抗值は初期值に対して 40〜50\%む增大する。しかしながら，保護塗料の耐湿 性を総合評価するための素子としては比较的短時間で 容易化有意差を得られるのでむむしろ好都合である。

コーティングは浸せき法で行ない，塗膜試験片と同 じ硬化条件 ( $150^{\circ} \mathrm{C}, 1$ 時間) で焼付けを行なった。鯐 膜の厚さは約 $30 \mu \mathrm{m}$ である。一試験条件あたりの素 子数 $n$ は 15 個之し, 各試験の測定値にはその平均值 を用いた。

\section{3. 試験方法}

〈3.1〉 温湿度処理条件而湿性の評価試験には 次の 3 とおりの温湿度処理条件を適宜用いた。なお。 各条件の末尾に示した時間は最終試駼時間である。

処理 (I)：室温， $97 \% \mathrm{RH}\left(\mathrm{K}_{2} \mathrm{SO}_{4}\right.$ 飽和水溶液によ ろ)，1箇年 $(8,760$ 時間) (主として讼膜試験 片の処理条件として使用)

処理 (II) : $40^{\circ} \mathrm{C}, 91 \pm 3 \% \mathrm{RH} ， 3,000$ 時間 (JIS C 5023 亿準拠了

処理 (III) : $70^{\circ} \mathrm{C}, 91 \pm 3 \% \mathrm{RH}, 3,000$ 時間(処理 (II) で有意差を得にくい試料の処理条件として用 意]

〈3.2〉 塗膜試験片の基本的性質 $\quad S_{0} \sim S_{25}$ の梁 膜試験片に対して，それぞれ処理（I）の前後怙よび必 要ならば啇宜その途中に执いて次の各項目の測定を行 ない，xによる塗膜の基本的性質の変化を調べた。

(1) 絶縁抵抗 試験片の体程抵抗率 $\rho$ および 表面抵抗率 $\sigma$ の温湿度処理過程伛おける経時变化を 測定した。

（2）高周波誘電特性 $3 \mathrm{MHz}$ 亿おりる誘電率 $\varepsilon^{\prime}$ およひ誘電正接 $\tan \delta$ を間げき変化法(12)を用いて 測定した。

（3）吸湿等温特性 石英ばねばかりを用いて数 点の相対湿度ふんい気中における吸湿平衡時の各試験 片の吸湿量を秤量し，吸湿等温特性を求めた。

（4）透湿率透湿カップ法 ${ }^{(13)}$ により測定した。

（5）水酸基の光学密度 赤外線吸収スペクトル の測定を行ない，特に $3,430 \mathrm{~cm}^{-1}$ に現われる O-H 伸 縮振動による吸収帯の強度加ら, 塗膜内の水酸基の光

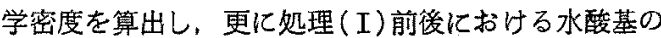
光学密度の变化率を求めた (付録参照)。

次に， $S_{x, y}$ の塗膜試験片に対しては，処理 (II)およ び (III)の前後でそれぞれ上記項目 (1)および（5)の測 
定を行ない，yによる塗膜の性質の変化を調べた。測 定值のは号つきは，試験項目 (1)，(3)扰よひ（4)で はおおむね $10 \%$ 以内，(2) 項では $5 \%$ 以内，また (5)項では $20 \%$ 以内である。

〈3.3〉抵抗体試料による評価 $x$ および $y$ の異 なる ME 登料によってコーティングされた多数の無 電界めっき抵抗体に対して各々処理 (II)およひ (III)を 行ない，処理後の抵抗值の初期值を基準とした変化率 を測定した。この評洒方法は，塗料の素子に対する接 着性など塗膜試験片に対する試験では䛨価できない多 数の因子を総合的に包括している。なお，抵抗変化率 の測定値のばらつきはいずれも $10 \%$ 以内に収まって いる。

\section{4. 充てん剂効果}

〈4.1〉電気的特性に対する充てん剂効果 処理 (I)の過程におりる $S_{0} \sim S_{25}$ の各染膜試験片の $\rho$ お よび $\sigma$ の経時変化の測定結果を図 1 亿示す。ただし $S_{15}$ については $S_{20}$ 之極めて近い結果を得たので，繁 雑を避けるため図中省略した。今後， $S_{15}$ については

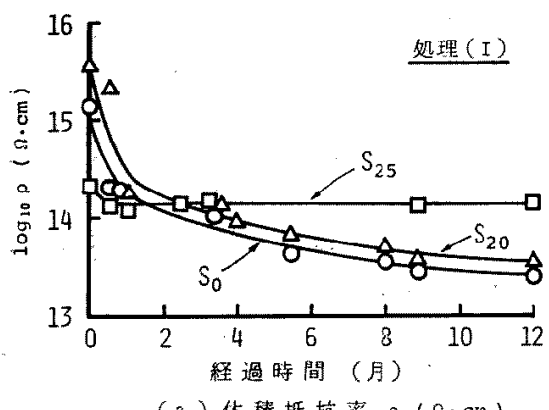

（a）体精抵抗率 $\rho(\Omega \cdot \mathrm{cm})$

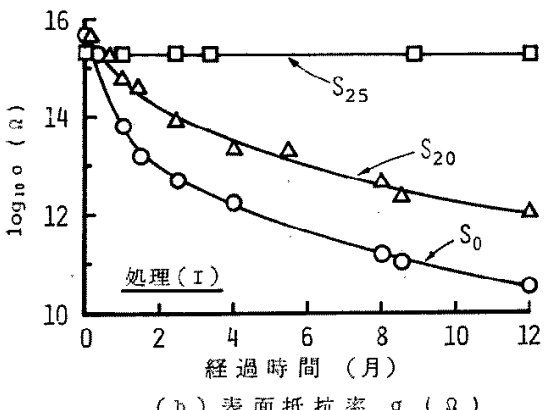

図 1 湿湿度処理 (I)による塗膜試料の $\rho お よ ひ ゙ \sigma$ の経時変化

Fig. 1. Changes of $\rho$ and $\sigma$ of film specimens under damp-heat test condition (I) with time elapsed.
表 1 滁膜試料の高周波誘電特性

Table 1. H.F. dielectric characteristics of film specimens.

\begin{tabular}{|c|c|c|c|}
\hline 試 料 & 条 件 & 誘䨖率 & $\begin{array}{c}\text { 誘電正接 } \\
\tan \delta\left(\times 10^{-1}\right)\end{array}$ \\
\hline \multirow{2}{*}{$S_{0}$} & 姏 理 前 & 3.04 & 214 \\
\hline & 処 理 㖟 & 3. 40 & 272 \\
\hline \multirow{2}{*}{$S_{20}$} & 処 理 前 & 5.60 & 172 \\
\hline & 䞘 理 後 & 5.80 & 194 \\
\hline \multirow{2}{*}{$S_{25}$} & 処 理 前 & 9.25 & 284 \\
\hline & 処 理 後 & 9.38 & 307 \\
\hline
\end{tabular}

椡定周波数：3MHz，処理条件：処理( I )[空温：97\%

しばしば同様の扱いをするととがある。

図1で特に注目されるのは， $S_{25} の \rho$ および $\sigma$ が 1 年経過後す初期値亡ほとんど变わらず，極めて安定し ている点である。 $S_{0} \sim S_{20}$ に関しては $\rho, \sigma$ とあに時 間の経過化伴って低下し， 1 年後には $\rho$ は $2 け た ， \sigma$ は 3 けた以上初期值より小さくなる。ただし， $x$ が大

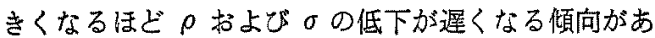
る。

次に，高周波誘電特性の測定結果を表 1 亿示す。処 理 (I) 後の各斌料の $\varepsilon^{\prime}, \tan \delta$ ともに初期值に比へて增 大しており，吸湿劣化した高分子材料洪通の傾向を 示している(14)。しかしながら，初期值を基準とした $\varepsilon^{\prime}$ および $\tan \delta$ の增加率は $x$ の增加之共に減少し， $S_{25}$ におりる值がいずれる最少となっている。

〈4・2〉吸湿およひ透湿特性に対する充てん剂勏果 処理 (I)の前後におりる各塗膜試料の吸湿等温特性 を図 2 に示す。四中の TW の吸湿等温線は，ことに 使用したものと同じ平均粒径を持つ $\mathrm{TW}$ 粉末につい て Kumins 氏らが測定した結果である(15)。

さて，図2の余白に親水性官能基を合む高分子材料 に，一般に適用される吸湿等温特性の模式図を示した

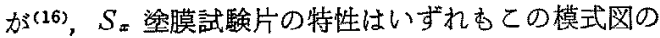
特徴，すなわち(I)〜（而）の3領域加成る逆 $S$ 字 形の特性を示している。てれらの領域はそれぞれ下記 のような異なった吸湿のメカニズムに支配されている と考觉られている。

領域 ( $(\mathrm{r})$ : 高分子材料内の無定形領域に遊離した親 水性官能基を吸着座として水分子が吸着する。

領域 (II)：領域 (I)の吸着座が飽和した後，既に水 素結合している親水性官能基にその結合を破壊して水 分子が吸着する。

領域 (III) : 水は高分子材料内の自由体皘部分や表面 にバルクの状態で存在する。

ちなみに，因 2 の测定結果を相対湿度でおおよを区 


\begin{tabular}{|c|c|c|c|}
\hline 织件 歌料 & $S_{0}$ & $S_{20}$ & $S_{25}$ \\
\hline 未 姏 理 & $-0-$ & $-\Delta$ & \multirow{2}{*}{$-1-$} \\
\hline 姏理(I) 溇 & $-\infty$ & $\rightarrow$ & \\
\hline
\end{tabular}

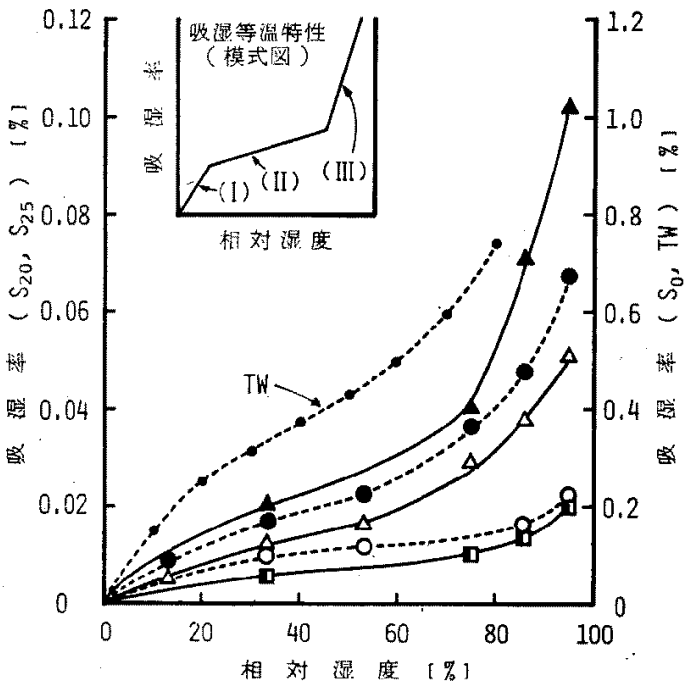

区 2 準膜試料の吸湿等温特性

Fig. 2. Moisture absorption isotherms of film specimens.

分すれば，領域（I），(II) および（五）はそれぞれ 0〜 30，30〜70 および 70〜100\% RH 程度となる。

図2から明ら加なよう，So の吸湿率は末処理試 験片においても $50 \% \mathrm{RH}$ で $0.12 \%$ 亡かなり大きく (例えば，PVCと同程度)，また処理（I）後には相対 湿度の全域にわたって 2 倍內上に增大し， TW 粉体の ほぼ1/2にも達する。しかしながら，TWが配合され ると $x=20,25$ と増すに従って吸湿率は急速に減少す る。また特筆すべきとととして，So〜 $S_{20}$ までの各㳯 膜試驗片の吸湿等温特性が好理 $(I)$ 前後で明りょう に異なるのに対して， $S_{25}$ には全く差が認められない ことが注目される。一般に，吸湿务化が進むにつれて 高分子銷や架橋部分の弱点の切断が起こり，その断点 に水分加吸着するために吸湿量加増加すると考えられ る。 $S_{25}$ ではこのような劣化の進行が極めて少ない上 考えら机る。

次に， $S_{0} \sim S_{25}$ 塗膜の透湿率之 $x$ 己の関連を好理 （I）の前後において測定した結果を図3に示す。未姏 理塗膜の場合には，xの増加に伴って透湿率は減少す る傾向が見られるが，その程度は極めて縰やかであ る。これに対して処理 $(\mathrm{I})$ 後の塗膜の吸湿率は， $x=$ 0 では末㐐理の場合の值よりも $70 \%$ 程度增大してい るが， $x$ が增加するにつれてはっきりと減少傾向を示 し，こ㧈伴って好理（I）の前後における透湿率の差

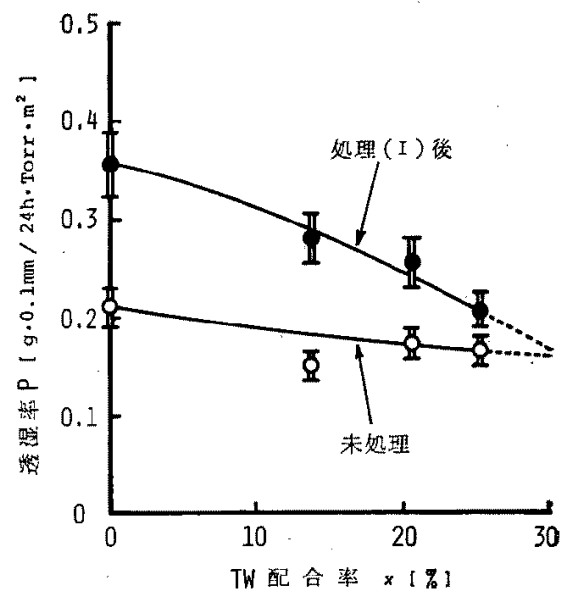

四 3 症膜試料の透湿率の 充てん剂配合率依存性

Fig. 3. Dependence of moisture permeability of film specimens of filler concentration.

む急速に縮少する。すなわち，処理後の透湿率の增 大，言い替元れば防湿能力の低下は TW の配合率が 增すにつれて効果的に排制されている。

〈4.3〉 水酸基の密度と充てん剂効果赤外線吸 収スペクトルの吸収強度は特定物質 (官能基)の密度に 対応する。ME 塗膜内に存在する種々の親水性官能基 のうち，水酸基は塗膜の硬化反応に大きく関与し(37), $\mathrm{TW}$ 粉体粒子の表面官能基としても相当量存在す る(9)。そこで， $x$ の異なる塣膜の赤外線吸収スペクト ルをそれぞれ測定し，特に水酸基の光学密度 $D$ およ ひ処理 $(\mathrm{I})$ 後の $D$ の变化率 $\Delta D$ を求めて水酸基の密 度の比較を行なった(付録参照)。その結果を図4 亿示 †。

$D$ の值は $x$ の堌加に伴って未好理招よで処理後の 試料とすに減少し，また $x$ の全域 $(0 \sim 25)$ にわたっ て末処理よりす処理後の試料のほうが大きくなってい る。特に迬目されるのは， $x=0 〜 20$ における $\Delta D$ の 値が 12〜13\% 程度であまり変化しないのに対し， $x=25$ でほ約 7\%と急減することである。すなわち, $S_{25}$ では処理後の水酸基の増加が他に比へて明らかに 低く抑元られている。

〈4.4〉抵抗体試料を用いた総合評価 $\mathrm{Ni}$ 系無電 界めっき抵抗体試料(10)(11) 亿，xの異なる各種 $\mathrm{ME}$ 塗 料をそれぞれ浸せき慗りし，処理(II)の過程における 抵坑值の変化率 $\Delta R$ を测定した結果を四 5 に示す。 $S_{0} \sim S_{20}$ でコーティングした抵抗体の $\Delta R$ は，時間の 経過と共にいずれも直線的に增大するが，その傾きは $x$ の增加上共に緩やかとなる。 $S_{25}$ でニーティングし 


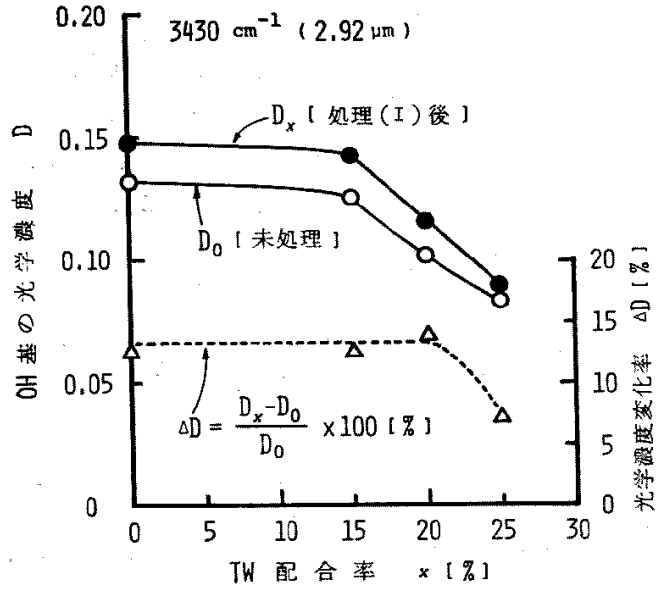

図 $4 \mathrm{OH}$ 基の $D$ および $\Delta D$ の 充てん剂配合率依存性

Fig. 4. Dependence of $D$ and $\Delta D$ of $\mathrm{OH}$ groups on filler concentration.

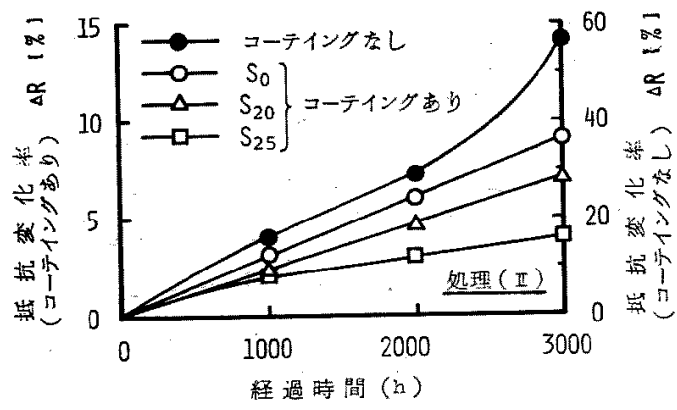

図 5 各種㳂料でコーティングした抵抗体試料の $\Delta R$ の温湿度処理 (II) による経時変化

Fig. 5. $\Delta R$ of resistors coated by paint samples under damp-heat test condition (II) with time elapsed.

たすのの $\Delta R$ の增加傾向は，1,000 時間までは $S_{20}$ の場合とほとんど変わらないが，それ以後の傾きが約 $1 / 3$ に減少し，抵抗值が安定化する傾向が見られる。

〈4.5〉充てん剤効果のメカニズム 以上の試跧 結果加ら， $x$ の增加と共に ME 汪膜の耐湿性が改善 されるが，その程度は $x=20$ までは比較的緩やか で， $x=25$ において急激に顕著となる共通の傾向が明 らかになった。耐湿性における充てん斉効果について は，耐湿性に少る有機材料（塗料樹脂）の一部が水分 に対して安定な無機材料（充てん剂）に置換された結 果であるとする比較的単純な概念に基づく説明がしば しば行なわれる。しかしながら，ME 淕瞙におりる上 述のような特異な充てん剂効果を促来の考え方で論ず ることは困難である。ここに得られた奏験結果のみに
基ついて，上述の充てん斉効果のメカニズムを断定す ることはもとより不可能であり，本論文の本旨であな いが，ME 樹脂㧍よび TW 粉体に関する従来の知見 屯併せて, 可能な耐湿性向上のメカニズムについて推 論を試みたので，その概略を述べる。

図 2 の吸湿等温特性の測定結果によれば，ME 樹脂 および TW 粉体は単独では共にかなり吸湿率が大き いにもかかわらず，両者を配合した塗膜の吸湿率は著 しく小さくなる。一方，四 4 亿示した水酸基の光学密 度 $D$ の測定結果加ら， $x$ の增加伴って督膜内の親 水性官能基は明らかに減少する。

さきに述べたように，TW粉体粒子の表面官能基は 罂膜の硬化反応の過程に架橋座として寄与する。徉っ て, $S_{0}$ 塣膜中に多量汇残存している親水性官能基が TW の表面官能基と架橋反応を行なうために，TW を 充てん剂として添加した $S_{15} \sim S_{25}$ 㳂㯖では水分子の 吸着座が減少すると考えられる。同時江図 2 中の模式 図において，領域（II）の説明に述べたような比較的破 䍡されやすい水素結合も減少するとすれば，四2およ び図 4 の測定結果を矛盾なく説明できる。

$S_{25}$ 染膜が特に著しい耐湿性を示す理由は明らかで はない。あえて推論を行なえば，互い代架橋反応を行 なう樹脂および充てん剂粒子表面の官能基が量的につ り合って，結果的に水分子の吸着座として働く親水性 官能基の量および不安定な水素結合の数が最小に近く なっていることが考えられる。

図3に示した透湿特性では，特に処理前の染膜には 他の測定結果に見るような顕著な $x$ に対する依存性が 見られない。これは測定時の高湿度側の相対湿度が $86 \%$ 之高く，透湿の過程が主として図 2 中の模式図の 領域（III）上同様に，バルクの状態で存在する水に支配 されるためである。しかしながら，充てん剂の添加に よって架橋部分や水素結合の破壊が抑制され，従って 透湿の経路となる樹脂内の自由体積の増加が抑制され る結果， $x$ か増すにつれて温湿度処理を経た徯の透湿 率の增加の割合屯小さくなる。

\section{5. 顔料添加の影響}

一般の塗料と暴なり，着色用顔料は白色塗膜に生じ る黄化を隐べいするという副次的な目的で配合されて おり，添加量す一般に数％程度上少ないので，塗膜 の諸特性に与える影響は従来ほとんど問題とされてい ない。しかしながら，CB 粉体粒子の表面にも種々の 官能基が存在することが見いだされており(9)，また表 面官能基が存在しない場合にも， $\mathrm{CB}$ 粉体粒子の表面 はグラフト重合しやすい性質を持つと言われている。 
従って，ME 樹脂内扔よび TW 粉体粒子表面の官能 基の間に，さきに推論したような量的つり合いの関係 があるとすれば，たとえわずかな添加量であっても顔 料が乷膜の諸性質に無視できない影響を与えることが 予想される。

そてで， $S_{20}$ 放よび $S_{25}$ 塗料をべースとして，それ ぞれ $\mathrm{CB}$ の配合率の異なる塗料を調製し，塗膜の性質 之 $\mathrm{CB}$ の配合率 yとの関連について充てん斉の場合 と同様の試験を行なった。

〈5.1〉絶縁抵抗 因1に見るように，絶縁抵抗 の経時変化は充てん剂効果を極めて典型的に示してお り，また導電材料である CB が垽膜の絶緑性能に与え る影響を調へる目的む兼执て測定を行なった。図6お よび図7は，それぞれ $S_{20, y}$ および $S_{25, y}$ の各淮膜試 料の体皘抵抗率 $\rho$ ○に対する依存性を，処理前。 処理 (II) 後および処理 (III)後の三つの異なる条件で測 定した結果である。

因6から明らかなように，処理前の $S_{20, y}$ の $\rho$ は $y$ $=0$ で $10^{16} \Omega \cdot \mathrm{cm}, y=2 \sim 8$ では 1 けた小さい1 $10^{15}$ $\Omega \cdot \mathrm{cm}$ のオーダを維持する。処理 (II) および (III) 後の のオーダはyの増加と共にほ洁直線的に低下する。 すなわち，y が大きいほど処理後の $\rho$ の低下がはな はだしい。

一方，S25,y の場合には，図7に示すように少なく टも $y=0 \sim 2$ までは処理後の $\rho$ の低下は 1 けた以内 にとどまるが， $y=5$ 以上では 2 けた以上に増加する。

表面抵抗率 $\sigma$ の測定結果は省略するが， $S_{20, y}$ 招よ び $S_{25, y}$ とすにそれぞれ $\rho$ とほぼ同様の傾向を示し ている。

〈5.2〉 水酸基の光学密度変化率 処理 (II)の前

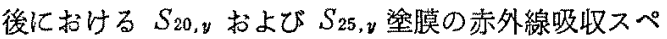
クトルの変化加ら，水酸基の光学密度の変化率 $\Delta D$

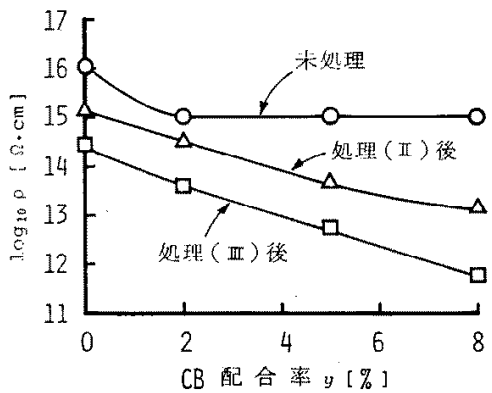

図 $6 S_{20, y}$ 沄膜試料の $\rho$ の 顔料配合率依存性

Fig. 6. Dependence of $\rho$ of $S_{20, y}$ film specimens on pigmens concentration.
を算出した。图8に $\Delta D$ の y 亿対する偖存性を示す。 $S_{25, y}$ の $\Delta D$ は $S_{20, y}$ よりも小さく, 処理 (II)後の 水酸䔄の増加が少ないととを示している。ただし，y $=2$ 以上では両者の $\Delta D$ とむに直線的に増加し，同 時仙両者の差は小さくなる傾向にある。ここで特に注 目されるのは， $y=0$ よりも $y=2$ に标ける $S_{20, v}$ の $\triangle D$ がわずかながら明らかに減少している点である。 一方， $S_{25, y}$ の $\Delta D$ については，y=0および 2 にお ける值には全く変化が見られない。

〈5.3〉抵抗体試料による総合評価充てん剂効 果の評価の場合之同榜に， $S_{20, y}$ および $S_{25, y}$ をそれ ぞれ無電界めっき抵抗体にコーティングして，処理 (II) 後の抵抗変化率 $\Delta R$ を測定した。図9に $\Delta R$ の $y$ による变化を示す。 $S_{20 . v} \oplus \Delta R$ が $y=2$ に和いて, いったん $y=0$ の值より あ减少し，以後ほぽ直線的に 増加しているが，乙のような変化の傾向は図 8 亿示し た $S_{20, y}$ の $\Delta D$ の $y$ 対する变化の傾向之良く一致

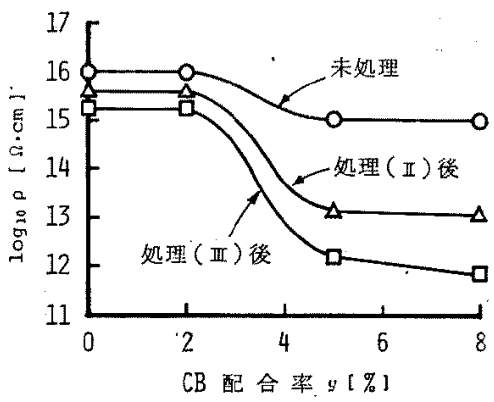

図 $7 S_{23, y}$ 塗膜武料の $\rho$ の 颜料配合率依存性

Fig. 7. Dependence of $\rho$ of $S_{25, y}$ film specimens on pigment concentration.

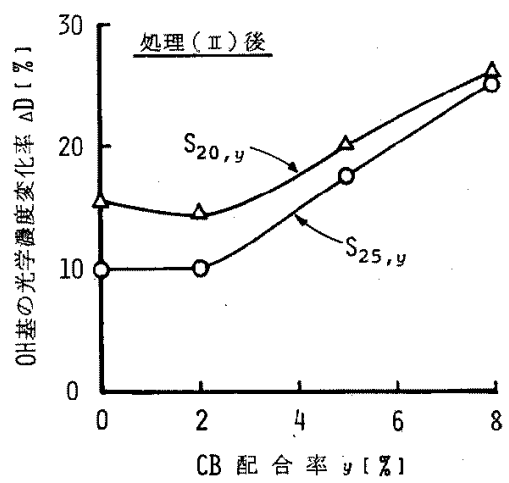

図 8 OH 基の $\triangle D$ の 颜料配合率依存性

Fig. 8. Dependence of $\Delta D$ of $\mathrm{OH}$ groups on pigment concentration. 


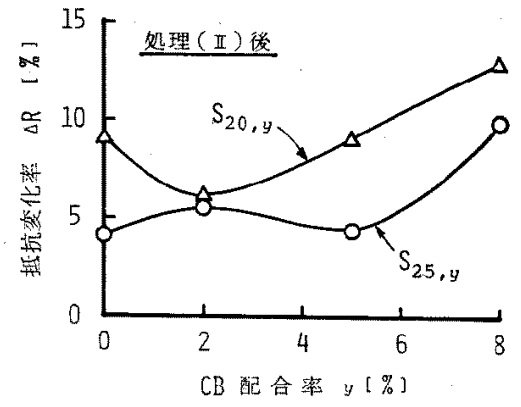

园 $9 S_{20, y}$ 拈よび $S_{25, y}$ 鋈料でコーティング した抵抗体の $\Delta R$ の顔料配合率依存性

Fig. 9. Dependence of $\Delta D$ of resistors coated by $S_{20, y}$ and $S_{25, y}$ paint samples on pigment concentration.

しているように見える。一方， $S_{25, y}$ の $\Delta R$ は全般的 に $S_{20, y}$ の值よりも小さいが, $y=2$ では小さなピー クを示して $S_{20, y}$ とにんご等しい值をしり， $y=5$ で は再びわずか減少した後急增する。この上うな梅猚 な变化を示す理由は明らかではない。

〈5.4〉顔料添加量の限度顔料添加の影隌を調 べる目的で行なった $\rho, \Delta D$ および $\Delta R$ の測定結果 (図6〜㘡 8)加ら，共通した傾向を見いだすととは困 難であるが， $S_{20, y}, S_{25, y}$ ともに少なくとも $y=2$ まで は耐湿狌に悪影翌はないと言える。むしろ $S_{20, y}$ の場 合には， $y=0$ よりあ $y=2$ のほうが而湿性がわずか ながら改善される傾向さえ見られる。〈4.5〉節に述べ た推諭に従えば，乙の現象は TW 粉体の量的な不足 分を $\mathrm{CB}$ が補った結果亡す考えられる。一方， $\Delta R D$ 测定結果（図9）から見れば， $S_{25, y}$ の場合には $y=5$ においても度い結果が得られている。しかしながら， $S_{25}$ をべースとして更に CBを $5 \%$ 配合すると，染料 の流動性はかなり低下し、コーティング工程の作業性 の点で問題を生ずる恐れがある。

\section{6. 最適配合率の決定}

以上の試験結果を総合すると，耐湿性の観点のみか ら見れば，TW 配合率 25\%の塗料をべースとして， $\mathrm{CB}$ 配合率は $2 \%$ 程度にとどめるのが最良と考えられ る。しかしながら，実用的な染料としては作業性，色 調などの因子も無視することはできない。実際，CB 配合率 $2 \%$ では塗膜の変色(黄化) 在隠ぺいするは淡 色に過ぎる難点がある。しかしながら，単純にCB 増量することは耐混性扔よび作業性に影響を与える恐 れがある。

そこで，検討の結果，色調の错点から CB 配合率を $3 \%$ に增置し，他方 $S_{20, v}$ に見られた TW の量的な

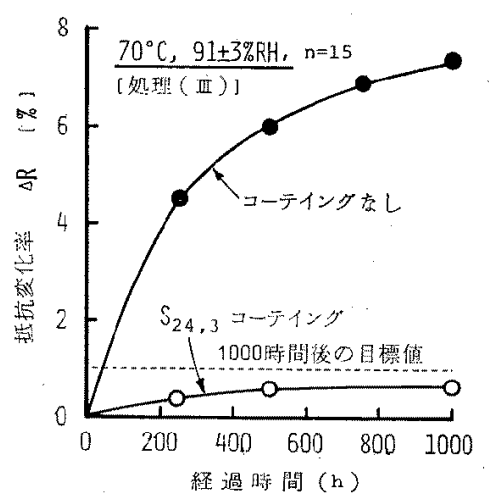

国 10 最適配:合率の塗料でコーティング した抵抗体の $\Delta R$ の経時変化

Fig. 10. $\Delta R$ of resistors coated by paint with optimum filler and pigment concentration with time elapsed.

不足分の CB による相補性にも期待して, TW 配合 率を $1 \%$ 減じて $24 \%$ 上沠定し，改めて保護梁料を調 製した。

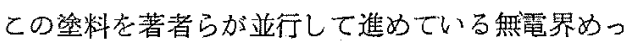
き抵抗体の実用化研究以执いて玶用した (11)。前述の ように，との抵抗体の酎湿性はそのままでは極めて悪 いので，安定化のための熱処理を施したうえでての塗 料によるコーティングを行なった。図 10 は処理(III) の条件下に放圈して抵抗变化率 $\Delta R$ 它测定した結果 で， 1,000 時間経過後の $\Delta R$ 在 $1 \%$ 以下と定めた目 標的能を十分満足している。

\section{7. まとめ}

$\mathrm{ME}$ 樹脂塗料の耐湿性改善を目的として，充てん剂 効果および着色用顔料添加の影響について検討した。 その結果を要約すると次のと扣りである。

（1） $x=25$ 以下の場合， $x$ の增加之共に塗膜の耐 漣性は改善される。

(2) $S_{25}$ 塗膜は耐湿性が著しく優れでおり，特異 充てん剂効果索す。

(3) そのメカニズムとして，ME 樹脂を TW 粉 体の間の量的なつり合いの関係について推論した。

(4) $S_{20}$ おるび $S_{25}$ に顔料として CB を配合する 場合，ともに少なくとも配合率 $2 \%$ までは耐湿性に影 響はない。

(5) $S_{20}$ に 2\% 程度のCBを添加すると，耐湿性 がむしる改善される傾向が見られる。

（6） 耐湿性以外の諸因子を加昧して決定した最適 配合率の烝料 $\left(S_{24,3}\right)$ を無電界めっき抵抗体の史用化 
研究に操用し，满足すべき結果を得た。

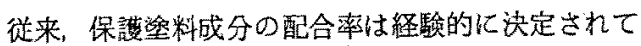

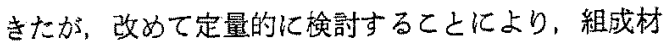

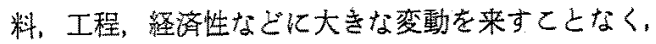
電子部品の信頼性を改善する余地のあるととを示し to

また，他の樹脂，充てん剂または顔料の組合せにつ いても，同㯲な充てん剂効果が期待できる。

最後に，誘電特性の测定に関して御助力をいただい た静風大学柿元 章教授、赤外線吸収火ペタトルの湘 定に関して有益な御助言を照わった東京都立大学小林 靖二教授に深く謝意を表します。

(昭和 56 年 2 月 16 日受付)

\section{文献}

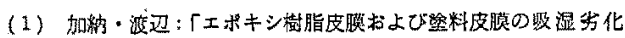
について」, 绍 44 霆気四学会速大

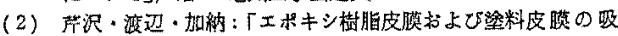

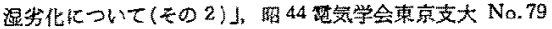

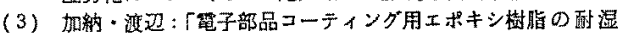
信賴性」，昭 46 眥気学全全大 No. 299

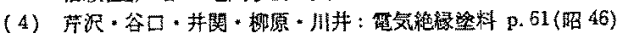

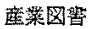

(5) W. K. Asbeck \& Maurice van Loo: "Critical Pigment Volume Relationships", Ind. \& Eng. Chem, 41, 1470 (1949)

(6) S. Eckhaus, I. Wolock \& B.L. Harris : "Porosity of Paint Fulms", ibid., 45, 426 (1953)

（7）茂木：「コイルエナメルの三，三の性频」，富士時報，No.10， $720($ 昭 35)

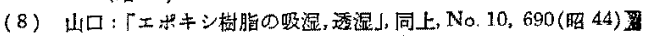

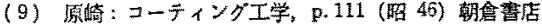

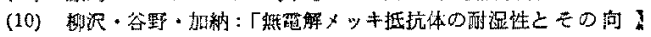

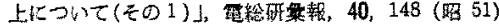

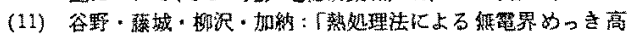

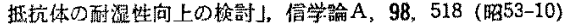

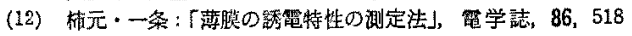
(昭 41-5)

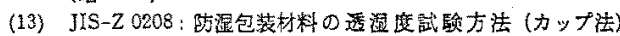
(昭 51)

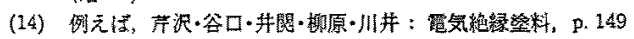

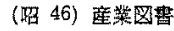

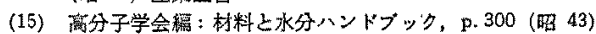

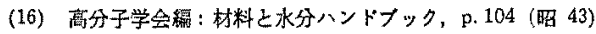

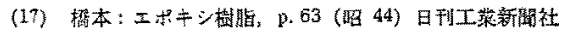

\section{付 録}

水酸基の光学密度 赤外線吸収スペクトルに虬い て，ある物質の密度とそれに対応する吸収帯の强度と の間に性，Lanbert-Beer の法勋加成り立ち，次のよ うな関倸がある。

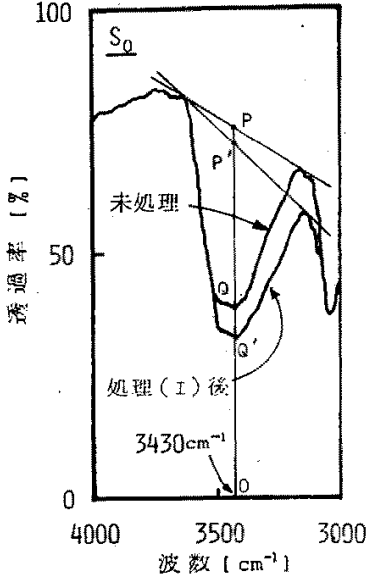

付区 1 光学密度 $D$ の決定法

app. Fig. 1. Determination method of optical density $D$.

$$
d \propto \log _{10} \frac{I_{0}}{I}
$$

ここに，d: 密度，I0およびI: それぞれ入

射光甫上ひ透過光の强度

(付1)式の右辺

$$
D=\log _{10} \frac{I_{0}}{I}
$$

を光学密度と呼び，物質の相対的な密度に対応する。

赤外線吸収スペクトルの湘定結果から実祭にD 求的方法を，付图 1 亿示した試料 $S_{0}$ の $3,420 \mathrm{~cm}^{-1}$

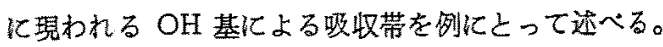

ます，末処理試料の場合には，I0 およびIはそれ ぞれ $\overline{O P}$ およひ $\overline{O Q}$ 〔い゙れる任意目盛化よる透過 率(\%)の読取值了に対灾する。従って，末如理試料の 水酸基の兆学密度 D。は次式で与えられる。

$$
D_{0}=\log _{10} \frac{\overline{O P}}{O Q}
$$

同捸に，処理後の試料の水酸基の光学密度 $D x$ は

$$
D_{x}=\log _{10} \frac{\overline{O P^{\prime}}}{O Q^{\prime}}
$$

である。とこで，本来一定であるばずのI。の值に対 心して $\overline{O P}$ まなは $\overline{O P \prime}$ のような值を用いる理由は， 近傍に別の大きな吸收带力存在する場合、その影響を 椪力莇えるためである。また，

$$
\Delta D=\frac{D_{x}-D_{0}}{D_{0}} \times 100(\%)
$$

を光学密度变化率と呼ぶ。 